\title{
Mapping spatial-temporal skipjack tuna habitat as a reference for Fish Aggregating Devices (FADs) settings in Makassar Strait, Indonesia
}

\author{
RACHMAT HIDAYAT ${ }^{1}$, MUKTI ZAINUDDIN ${ }^{2, \vartheta}$, ACHMAR MALLAWA ${ }^{2}$, MUZZNEENA AHMAD MUSTAPHA ${ }^{3}$, \\ A. RANI SAHNI PUTRI ${ }^{1}$ \\ ${ }^{1}$ Doctoral Program, Faculty of Marine Science and Fisheries, Universitas Hasanuddin. Jl. Perintis Kemerdekaan Km.10, Makassar 90245, South \\ Sulawesi, Indonesia \\ ${ }^{2}$ Faculty of Marine Science and Fisheries, Universitas Hasanuddin. Jl. Perintis Kemerdekaan Km.10, Makassar 90245, South Sulawesi, Indonesia. \\ Tel./fax.: +62-411-586025, "email: muktizunhas@gmail.com \\ ${ }^{3}$ Faculty of Science and Technology, Universiti Kebangsaan Malaysia. 43600 UKM, Bangi Selangor, Malaysia
}

Manuscript received: 3 June 2021. Revision accepted: 10 July 2021.

\begin{abstract}
Hidayat R, Zainuddin M, Mallawa A, Mustapha MA, Putri ARS. 2021. Mapping spatial-temporal skipjack tuna habitat as a reference for Fish Aggregating Devices (FADs) settings in Makassar Strait, Indonesia. Biodiversitas 22: 3637-3647. Skipjack tuna (Katsuwonus pelamis) has a high economic value in the international market. Catching skipjack tuna using fish aggregating devices (FADs) without knowing its habitat characteristics can damage the ecosystem. This study aimed to determine suitable fishing areas for setting skipjack's FADs. The data used included that on catch, sea surface temperature (SST), and sea surface chlorophyll- $a$ (SSC) in the Makassar Strait obtained for 2017-2019. The generalized additive model (GAM) and empirical cumulative distribution function (ECDF) analyses were used to investigate the skipjack's tuna habitat. A pelagic habitat index (PHI), with PHI > 75\%, was applied to determine suitable FAD positions. The gravity center of the skipjack tuna habitat for ten months (January-October 2020) was calculated to validate the model's results. The results showed that the optimum SST range was from $28.78^{\circ} \mathrm{C}$ to $31.25^{\circ} \mathrm{C}$, while the SSC from 0.18 to $0.28 \mathrm{mg}$ $\mathrm{m}^{-3}$. The best skipjack habitats in the southern Makassar Strait are criterion 4 (PHI > 90\%) and criterion 3 (PHI $\left.=85-90 \%\right)$, having a relatively high consistency of the average PHI values. These results can help determine the optimal positions for setting FADs to benefit the global management and sustainable development of skipjack tuna fisheries.
\end{abstract}

Keywords: Fish Aggregating Devices, Katsuwonus pelamis, Pelagic Habitat Index, satellite data, skipjack tuna, sustainable fisheries

\section{INTRODUCTION}

Spatially and temporally, the science of oceans is very complex. Various physical, chemical, and biological events appear to have a significant impact in identifying the habitat characteristics of aquatic organisms (Worm et al. 2003; Safruddin et al. 2019). Therefore, many researchers have studied the habitats of organisms. Habitat correlates with the environmental parameters or the oceanographic parameters (Polovina and Howell 2005). Fish habitats are usually described as areas with high biological activity and are influenced by environmental factors, so they are essential in controlling the distribution and migration of marine organisms (Malakoff 2004; Palacios et al. 2006; Sydeman et al. 2006). Fish is one of the most important organisms for humans. Several types of fish, such as tuna and skipjack tuna (Katsuwonus pelamis), have high economic value (Galland et al. 2016). In the last few decades, skipjack tuna has become one of the contributors to the global production economy, amounting to 3 million tons/year (FAO 2016). Compared to other tuna species' total production, skipjack tuna production reached $58.1 \%$ of the total tuna catch in 2010 (FAO 2018). Even in 2018, the total catch of tuna amounted to 5.1 million tons, dominated by tropical tuna constituting $95 \%$ of the total (ISSF 2020).
Makassar Strait is an area that has a high potential for catching skipjack tuna. The potential for skipjack tuna fishing in the Indonesian Fisheries Management Area, 713 in 2016, was recorded at 419,342 tons with moderate utilization status, including the Makassar Strait (KKP 2017). In recent years, fishing aids such as fish aggregating devices (FADs) have become increasingly popular since they minimize the time for finding tuna schools and reduce operation costs (Davies et al. 2014). In addition, the service life of FADs is also quite long. The results of interviews with fishers, FADs can survive productively in waters for 5 - 10 years. In the Makassar Strait area, the distribution of FADs used is still traditional, with most using FADs anchored on the sea surface. The main construction of FADs consists of a clump body which also functions as a buoy, attractor, main rope, and ballast. The materials used are also still traditional, where the body of the FAD is usually made of bamboo combined with foam as a buoy with dimensions of about 3 (length) x 2 (width) x 0.5 (height) $\mathrm{m}$. The attractor usually uses natural leaves from the Cycadaceae family, such as coconut (Cocos nucifera) and palm (Nypa fruticans) leaves. Concrete is used as ballast for FADs with a weight ratio adjusted to the depth of the FAD setting area. The main rope used is usually made of polyethylene with a rope diameter adjusted to the setting area of FADs. 
Tropical tuna and tuna species such as skipjack tuna, which is a high-value species, are among the most abundant species found around FADs (Artetxe-Arrate et al. 2020 ). About $40 \%$ of the world's tuna catch comes from the use of FADs (Taquet 2013). The associative behavior of fish to approach floating objects encourages these objects to assist certain fishing activities (Matsumoto et al. 2016; Rodriguez-Tress et al. 2017; Khan et al. 2020). Although they increase the productivity of fishing, FADs can have negative impacts if they're placed without proper supervision (Cheung et al. 2009; Marshall et al. 2009; Davies et al. 2014). The use of FADs can increase the bycatch during the fishing operation (Mallawa et al. 2018). Usually, a strong associative behavior between different organisms can lead to the catch of non-target organisms (Romanov 2008; Dagorn et al. 2012). Another supporting factor is the high density of FADs in the waters caused due to their settings without referring to the correct potential areas (Marsac et al. 2000; Hallier and Gaertner 2008).

This research attempts to show the potential areas for placing FADs by studying the characteristics of suitable habitats for skipjack tuna. The combination of the skipjack habitat and the associative behavior of fish with regard to floating objects are the basis for making an accurate area estimate as a reference in determining the positioning of FADs in waters (Lezama-Ochoa et al. 2018). The main parameters in identifying the skipjack habitat are sea surface temperature (SST) and sea surface chlorophyll- $a$ (SSC), as both are positively correlated to the distribution of marine organisms, especially fish (Andrade 2003; Zainuddin et al. 2008; Zainuddin et al. 2017). SST is an essential variable in influencing the growth of phytoplankton and directly affects the physiological condition of fish (Yuniarti et al. 2013). Meanwhile, SSC is closely related to productivity, which is indicated by the amount of phytoplankton biomass, the first food chain for pelagic fish (Kunarso et al. 2011). The magnitude of the level of water fertility can be estimated by knowing the concentration of SSC. The main objective of this study is to provide a reference for the placement of FADs for skipjack fishing areas in the Makassar Strait.

\section{MATERIALS AND METHODS}

\section{Study area and dataset}

The research was conducted in the waters of the Makassar Strait, with fishing bases in Barru, Pinrang, and Pangkep districts, Indonesia. The spatial boundaries of the Makassar Strait used are $115.38-120.10^{\circ} \mathrm{E}$ and $1.11^{\circ} \mathrm{N}$ $8.45^{\circ} \mathrm{S}$ (Figure 1). These coordinates refer to the Fishing Management Area (FMA) 713, consisting of four waters: Makassar Strait, Bone Gulf, Flores Sea, and Bali Sea. Makassar Strait was chosen because these waters are fertile areas with a large production of skipjack tuna. In addition, the status of the use of skipjack tuna in these waters is still in a moderated state (KKP 2017).

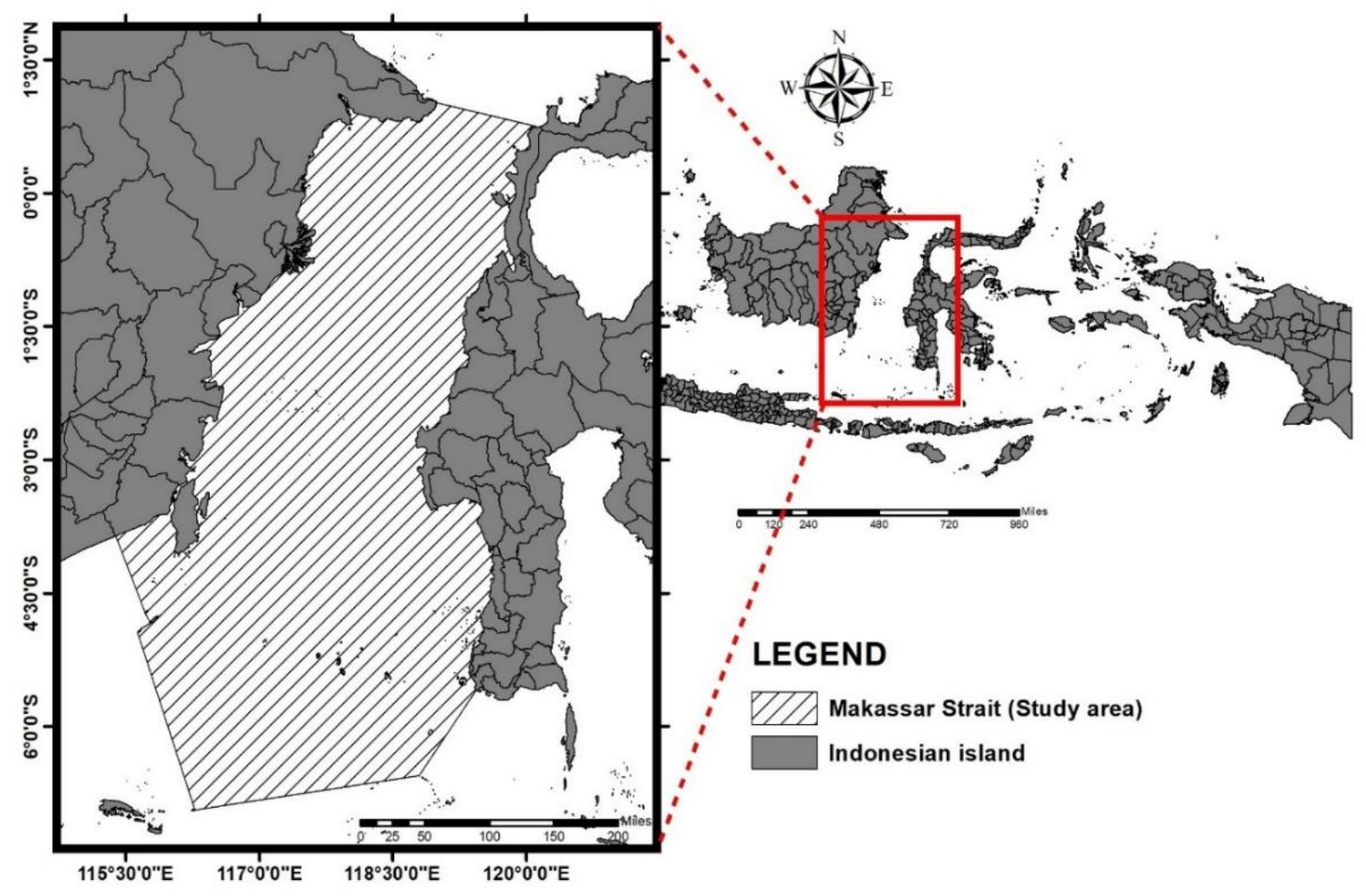

Figure 1. The study area in Makassar Strait, Indonesia 
Observation data on skipjack tuna

Data on skipjack tuna catch were collected directly by following the purse seine fishing operation in the Makassar Strait. The total observation data comprised 56,542 skipjack tuna from 229 fishing efforts. The fishing effort used is not a trip but the number of fishing operations. Catch per unit effort (CPUE) can be calculated using Total catch (skipjack tuna)/fishing effort (fishing operation). Data on skipjack tuna catch ware collected directly by following the purse seine fishing operation in the Makassar Strait. The total observation data comprised 56,542 skipjack tuna from 229 fishing efforts. The fishing effort used is not a trip but the number of fishing operations. Catch per unit effort (CPUE) can be calculated using Total catch (skipjack tuna)/fishing effort (fishing operation). The Catches data were collected from January 2017 to December 2019.

\section{Remotely sensed oceanographic data}

The SST and SSC data were obtained from Aqua's satellite imagery with a moderate resolution imaging spectroradiometer (MODIS) sensor. This data was accessed from https://oceancolor.gsfc.nasa.gov/ with a $9 \mathrm{~km}$ or $4 \mathrm{~km}$ spatial resolution. This study uses one calendar month's worth of data $(28,29,30$, or 31 days depending on the month) to be the monthly average data with a resolution of $4 \mathrm{~km}$ from 2017 to 2019 . The data categories are SST 26 to $32^{\circ} \mathrm{C}$, and SSC 0 to $1.5 \mathrm{mg} \mathrm{m}^{-3}$ in waters is used to avoid bias in coastal waters. The data was extracted using the SeaDAS v.7.5.3 analysis software. According to the distribution of skipjack tuna, oceanographic factors as a predictor proved to be effective in Indonesian waters, particularly the Makassar Strait, Bone Gulf, and Flores Sea (Zainuddin et al. 2017; Hidayat et al. 2020).

\section{Data analysis}

Statistical model to determine the relationship between an environmental variable and skipjack tuna catch

We employed the GAM method using the R-Studio software (version 1.3.959). GAM analysis is a nonparametric statistical analysis that corresponds to nonlinear data (Zainuddin et al. 2008; França et al. 2012). The used GAMs function comes from the mgcv package, with the number of catches as a response variable and environmental factors (SST and SSC) as predictor variables. The GAM is as follows (Guisan et al. 2002):

$$
g(\mu \mathrm{i})=\alpha+s(S S T)+s(S S C)+\varepsilon
$$

Where: g: the fine spline function; ui: the expected value of the response variable; a: the constant-coefficient model, s: a predictor variable smoothing function; $\varepsilon$ : a random error term.

In addition to using the GAM to determine the distribution of catch based on oceanographic parameters, this study uses the ECDF analysis. The results of this analysis provide specific references to the optimum range of SST and SSC values for the catch. This method is divided into several stages (Andrade and Garcia 1999; Zainuddin et al. 2008) as follows:

$$
f(t)=\frac{1}{n} \sum_{t=1}^{n} l(x i)
$$

With the indication function:

$$
\begin{aligned}
& l(x i)=\left\{\begin{array}{l}
1, \text { if }(x i \leq t) \\
0, \text { otherwise }
\end{array}\right\} \\
& g(t)=\frac{1}{n} \sum_{t=1}^{n} \frac{y i}{y} l(x i) \\
& D(t)=\max |f(t)-g(t)|
\end{aligned}
$$

Where: $f(t)$ : empirical cumulative distribution function (ECDF) $\mathrm{g}(\mathrm{t})$ : catch-weighted cumulative distribution function; $1(x i)$ : indication function; $D(t)$ : the absolute value of the difference between the two curves $f(t)$ and $g(t)$ at any point $\mathrm{t}$, assessed by the standard Kolmogorov-Smirnov test; $\mathrm{n}$ : the number of fishing trips; xi: the measurement for satellite-derived oceanographic variables in a fishing trip; $\mathrm{i}, \mathrm{t}$ : an index ranking the ordered observations from the lowest to the highest value of the oceanographic variables; yi: the catch per unit effort (CPUE) obtained in a fishing trip i; $y$ : the estimated mean of CPUE for all fishing trips.

The $\max$ coordinate label represents the specific value of the variables at which the difference between the two curves $(|\mathrm{f}(\mathrm{t})-\mathrm{g}(\mathrm{t})|))$ was absolute.

\section{Determining skipjack habitat using environmental probability indices}

In determining the skipjack tuna habitat in the Makassar Strait, we used the fish abundance index value and combined it with the fishing frequency index associated with oceanographic variables (SST and SSC). The multiplication index was obtained from the total CPUE at certain intervals in a histogram. Thereafter, the total CPUE in an interval was divided by the highest CPUE value of all intervals. This calculation was repeated as many times as the oceanographic variables produced an environmental probability value based on the CPUE (Eq. 5). Meanwhile, the fishing frequency index was obtained from the frequency value at certain intervals divided by the highest frequency value. Subsequent calculations followed the same method to obtain environmental probability values based on the fishing frequency (Eq. 6). The determination of the best habitat was calculated based on the mean of probability, which had a value of more than 0.75 (PHI > $75 \%$ ). Meanwhile, the lowest PHI value indicated either an unsuitable area or area without skipjack tuna habitats (Eq. 7). Furthermore, the probability data visualization of all variables was carried out using ArcGIS 10.2 software. The $\mathrm{PHI}$ is as follows (Zainuddin et al. 2017):

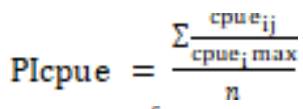

$$
\begin{aligned}
& \text { PIf }=\frac{\sum_{f_{i} \text { insix }}}{n} \\
& \text { PHI }=\frac{\text { PIcpue }+ \text { PIf }}{n}
\end{aligned}
$$


Where: PHI: the pelagic habitat index; Plcpue: the mean probability index for skipjack tuna based on the relationship between CPUE and the oceanographic variables (SST and SSC) for each histogram graph; Plf: the mean probability index based on the relationship between fishing frequency and the oceanographic variables for the histogram graphs; cpue $_{\mathrm{ij}}$ : the value of CPUE concerning the oceanographic variable-i for class interval-j; cpue ${ }_{i}$ max: the maximum value of CPUE among the oceanographic variables; $\mathrm{f}_{\mathrm{ij}}$ : the value of fishing frequency in relation to the oceanographic variable-i for class interval- $j$; $f_{i}$ max: the maximum value of fishing frequency among the oceanographic variables; $n$ : the total number of variables.

\section{Persistent habitat for skipjack tuna}

The mapping of the persistent habitat of skipjack tuna in the Makassar Strait shows a high probability indication in a water area (> $75 \%$ probability). It makes persistent maps of the skipjack tuna habitat using the monthly average habitat composition data for three years (20172019). The criteria for the map values range from zero (0) to (3), where zero (0) denotes an area that is considered to have no skipjack tuna habitats or a probability value of < $75 \%$, while criteria one (1), two (2), and three (3) describe the persistence habitat of skipjack tuna in a specific area for one year, two years, and three years respectively.

\section{The gravity center of potential areas for setting FADs}

The gravity center of a potential area describes a specific area in the form of an imaginary point and represents the state of the area surrounding it. Calculating the center of gravity of a fishing area involves calculating the gravity center of a fixed object, but there is a fundamental difference between a moving fish and a fixed object. The gravity center's ability to characterize the potential areas of fish distribution reflects the fishing ground's credibility. This method represents specific water characteristics in several coordinate points, and in the end, these coordinates are tested based on their performance in several months outside the time of analysis (JanuaryOctober 2020). The formula used to determine the gravity center for a potential area is as follows (Zainuddin et al. 2019):

$$
G C_{i j}=\frac{\sum L_{i j} P H I_{i j}}{\sum p H I_{i j}}
$$

Where: $\mathrm{GC}_{\mathrm{ij}}$ : the center of gravity of a potential area; $\mathrm{L}_{\mathrm{ij}}$ : the latitude and longitude of fishing point; $\mathrm{PHI}_{\mathrm{ij}}$ : the pelagic habitat value at position $i j$.

\section{RESULTS AND DISCUSSION}

\section{Temporal variation of catch data and environmental variables}

During the study period, the highest CPUE value was observed in October (Figure 2.A). The average catch of skipjack tuna in October was 722 fish/sets. The SST and SSC values were in the range of $27.05-31.50^{\circ} \mathrm{C}$ with a mean of $29.78 \pm 0.94^{\circ} \mathrm{C}$ (Figure 2.B) and $0.15-0.59 \mathrm{mg} \mathrm{m}^{-3}$ with a mean of $0.27 \pm 0.09 \mathrm{mg} \mathrm{m}^{-3}$ (Figure 2.C). The interesting oceanographic characteristics provided in Figures 2.B and 2.C were seen in June, when a relatively low SST increased SSC. These events were linear with nearly consistent warm SST events in the other months in line with the consistent SSC values in the range 0.2-0.3 mg $\mathrm{m}^{-3}$. Apart from the highest CPUE value in October, the low CPUE value seen in December tended to occupy a relatively high SST and a fluctuating concentration of SSC.

\section{Skipjack tuna's relation to oceanography variables}

Oceanographic data has a significant relationship, especially with SST parameters (Tseng et al. 2010; Wang et al. 2016). As seen in Figure 3, the GAM test results show that the skipjack tuna catches have a relationship with SST parameters (Figure 3.A) and SSC (Figure 3.B). These results show that several models have high significance values (Table 1). The best model for testing is determined by considering the AIC value and the deviation explained as the basis for the conclusion. Akaike information criterion (AIC) is the best model assessment method for evaluating the catch effect of skipjack tuna. The assessment is accurate when the AIC value gets the smallest value of all the models tested (Johnson and Omland 2004; Mugo et al. 2010).

The deviation explained is used to find the total deviation described in a particular model. Referring to the AIC values and deviation explained, the best model should combine SST and SSC. Table 1 shows that the AIC value obtained is 3107.54 , and the explaining deviation is $23 \%$. The GAM test results show a significant value of SST and SSC. The determination of SST and SSC ranges using ECDF analysis is required to obtain the optimal range of values. The optimum range of SST and SSC is a range of values explaining the distribution of skipjack tuna in waters. In the ECDF analysis, the optimum range is explained by looking at the distribution of the $D(t)$ value which is the difference between the two curves $f(t)$ and $g$ (t). The ECDF method shows that the optimum SST range is between 28.78 and $31.25^{\circ} \mathrm{C}$ (Figure 4.A). The SSC optimum value in this study was between 0.18 and $0.28 \mathrm{mg}$ $\mathrm{m}^{-3}$ (Figure 4.B).

\section{Determining skipjack habitat using environmental probability indices}

The probability of each oceanographic parameter is derived from the relationship between catch and oceanographic parameters (Figure 5). The probability value is the CPUE value for each interval divided by the largest CPUE value for a particular variable. This method applies to SST and SSC as well as the fishing frequency of each variable. Note that the best SST value was around $29^{\circ} \mathrm{C}$ to represent CPUE, which is relatively high at $\pm 35 \%$ (Figure 5.A) and capture frequency $\pm 23 \%$ (Figure 5.C). As for SSC, this study obtained an extraordinary SSC value of 0.2 $\mathrm{mg} \mathrm{m}^{-3}$, representing $\pm 57 \%$ CPUE (Figure 5.B) and $\pm 48 \%$ capture frequency (Figure 5.D). The focus of this study is to reveal the characteristics of PHI that occurred in October from 2017 to 2019 (Figure 6). 

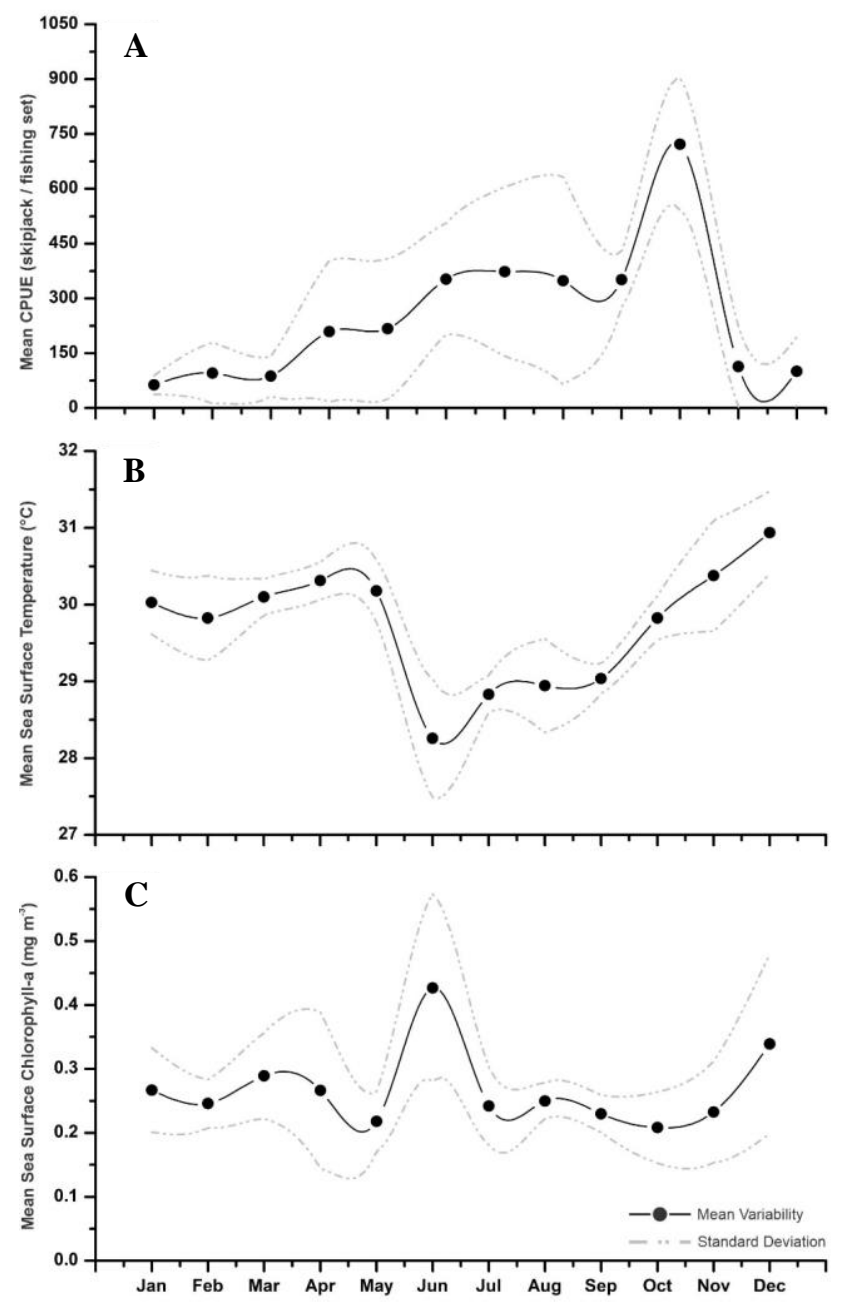

Figure 2. Temporal variability of the (A) Mean CPUE of skipjack fishery, (B) Mean SST, and (C) Mean SSC 2017-2019 in Makassar Strait, Indonesia

\section{Persistent spatial distribution of pelagic habitat hotspots for skipjack tuna}

For three years (2017-2019), persistent habitat was found in different areas every month. In this study, the biggest habitat was observed in October with the highest average CPUE (Figure 2.A) and the habitat area reached
$152656.14 \mathrm{~km}^{2}$ for areas with one-year persistence, $46338.91 \mathrm{~km}^{2}$ for two-year persistence and $19755.36 \mathrm{~km}^{2}$ for three-year persistence. This study validates the data (Figure 6) by overlaying the PHI raster's fishing spot in October 2017, 2018, and 2019. The results are very positive where the fishing spot is located right in the PHI quarter 3 area (PHI> 75\%). The testing of PHI values was also carried out in August-October 2020. This test aimed to see the consistency of the model with data that does not include analytical data. The test results show that the coordinates of fishing spots in August-October 2020 are in the areas with high PHI values (PHI > 75\%), so this model consistently shows the appropriate fishing areas (Figure 7). The persistence and consistency of the model for three years (2017-2019) in October therefore becomes a reference for placing the best FADs in the Makassar Strait (Figure 8).

\section{Prediction performance of the potential fishing area}

Based on Figure 8, there are four criteria for high PHI areas: areas with PHI values of $75-80 \%$ (criterion 1 ), 80 $85 \%$ (criterion 2), $85-90 \%$ (criterion 3), and > 90\% (criterion 4). The development of these criteria was aimed at proving the persistence of the area relevant to the obtained PHI value. The formation of imaginary point utilizes the center of gravity method for each location that has a probability based on the criteria in Figure 8.B. This method produced 21 coordinates; all of these points were tested using the PHI raster for the period of January to October 2020 to note the performance for each coordinate (Figure 9.A). The test results obtained the best performance for the criterion where PHI $>90 \%$ (red), with an average PHI value for January-October 2020 of $\pm 71 \%$ (Figure 9.B). In addition, this study also shows that the performance of criterion 3 is good, where the average PHI from January to October 2020 was $\pm 67 \%$ (yellow). For details, in Figure 9.C, the average monthly performance of criterion 4 shows the best consistency, while criterion 3 has a pattern that is almost the same as criterion 4 . This study showed the area with categories 3 and 4 dominant in the southern Makassar Strait areas and can be applied to find a potential area for setting FADs in the Makassar Strait.

Table 1. The results of statistical model testing using GAM. Deviation explained and AIC are the determinants in selecting the best model that can be used for the optimum effect of environmental parameters on the skipjack tuna catches

\begin{tabular}{|c|c|c|c|}
\hline Model & Deviation explained (\%) & AIC & p-Value \\
\hline (SST) & 19.50 & 3110.94 & $<0.001$ "****" \\
\hline (SSC) & 6.73 & 3149.45 & 0.0597 “.” \\
\hline$(\mathrm{SST})+(\mathrm{SSC})$ & 23.00 & 3107.54 & $<0.001$ "****" \\
\hline
\end{tabular}

Note: Signif. codes: 0 ‘***’ 0.001 '**’ 0.01 ‘*’ $0.05^{\prime}$ '’ 

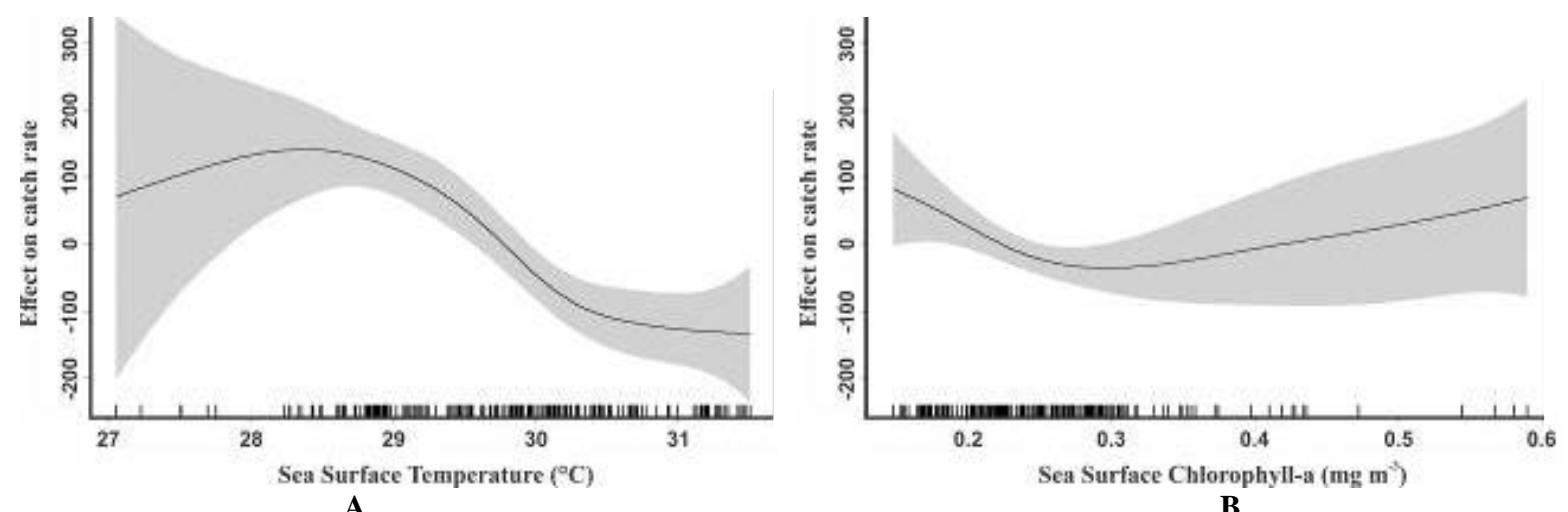

Figure 3. GAM derived effect of oceanographic variables, A. SST and B. SSC on skipjack tuna CPUEs. The shaded region above and below the line indicate $95 \%$ confidence intervals. The $\mathrm{x}$-axis represents the range of oceanographic factor values. The $\mathrm{y}$-axis is the partial effect of the variable; the shadow portion is the standard error confidence interval

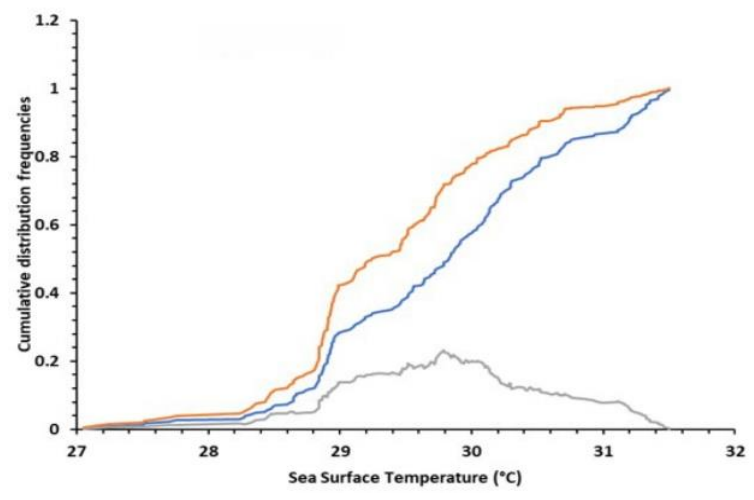

A

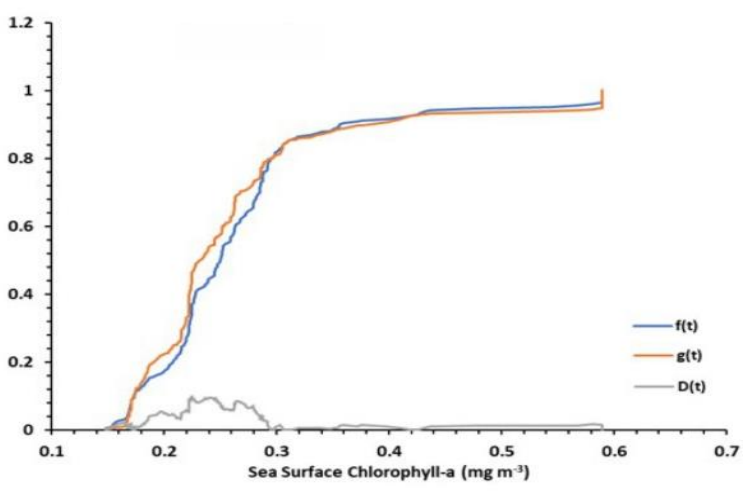

B

Figure 4. The ECDF result between CPUE and SST (A) and how it relates to SSC (B) during 2017-2019

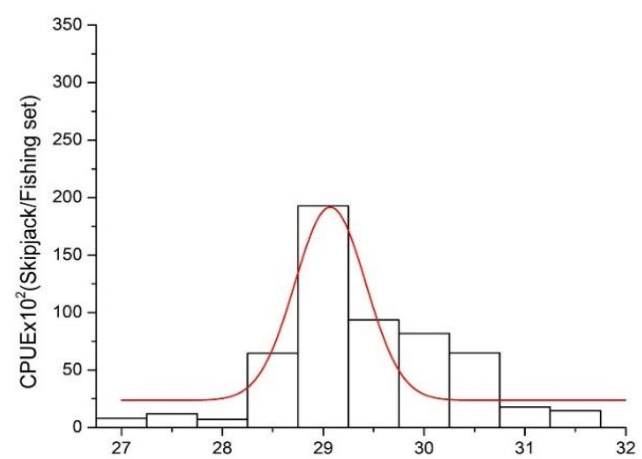

A

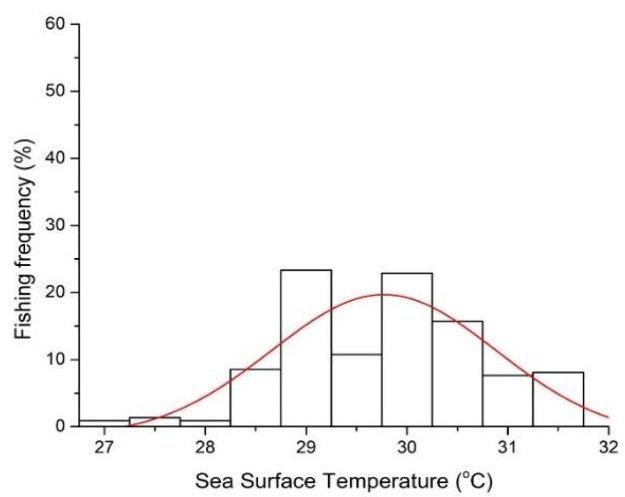

C

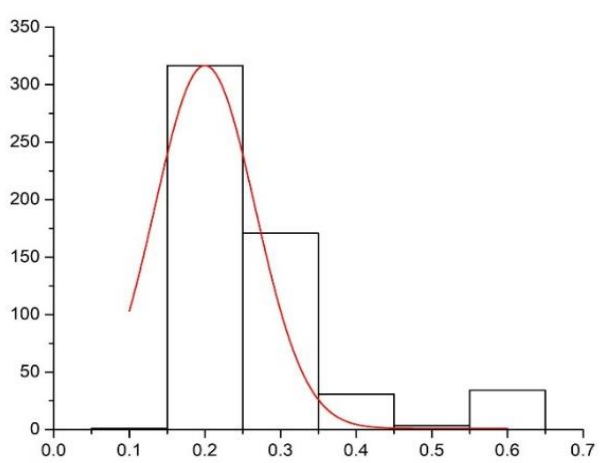

B

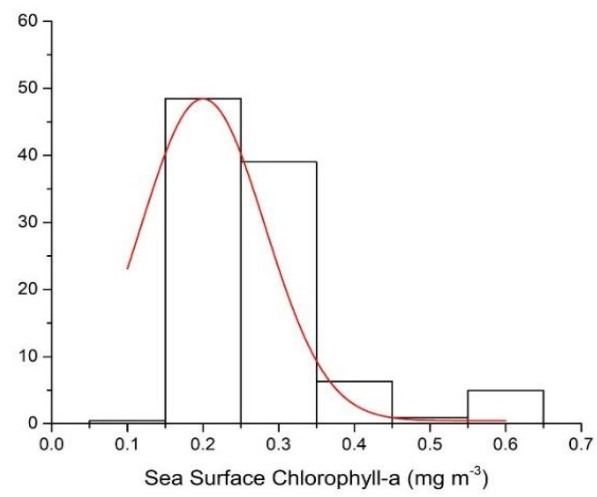

D

Figure 5. Total skipjack tuna CPUEs (skipjack/fishing set) with SST (A) and SSC (B); the relation of fishing frequency to SST (C) and SSC (D) 

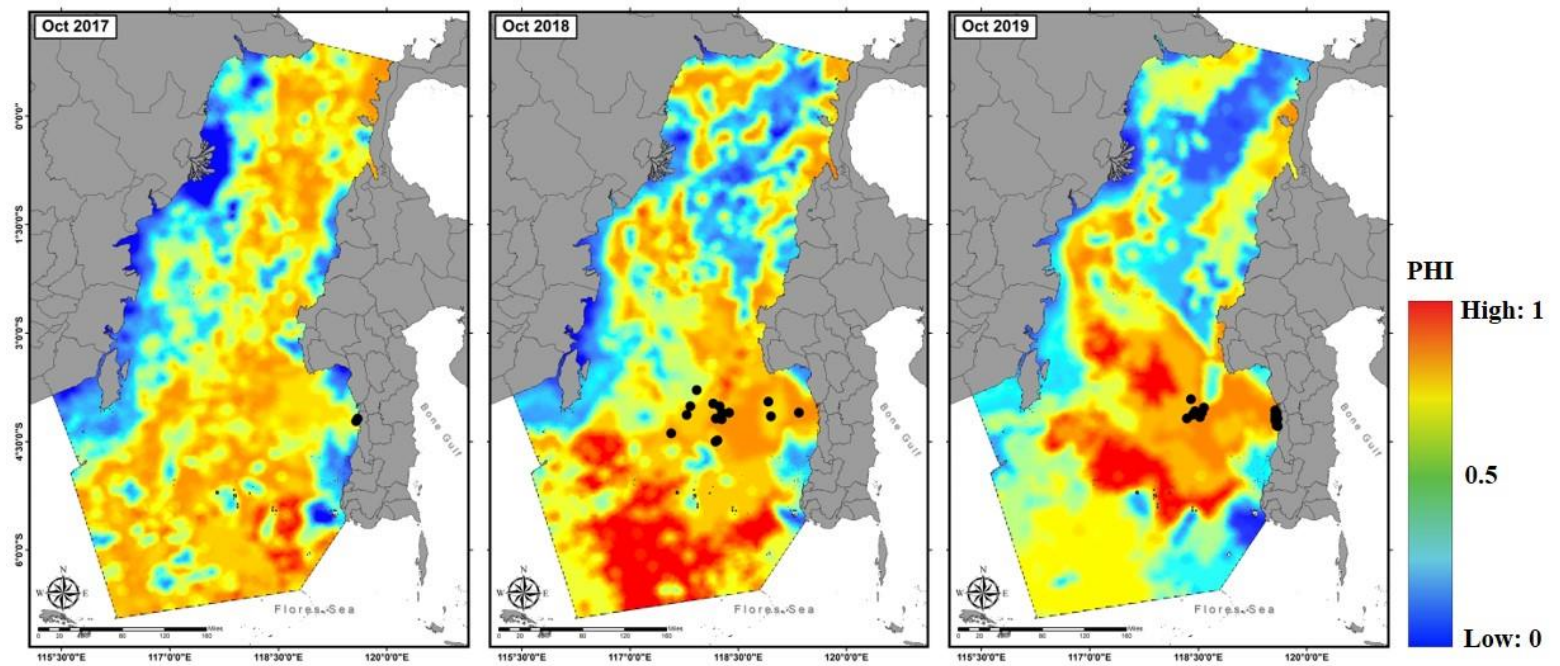

Figure 6. The PHI map for October 2017-2019. The black dots on the map are the fishing spots for that month. The color gradient represents the PHI value, whereby the areas with the highest value are represented in red, and blue colors represent the lowest values
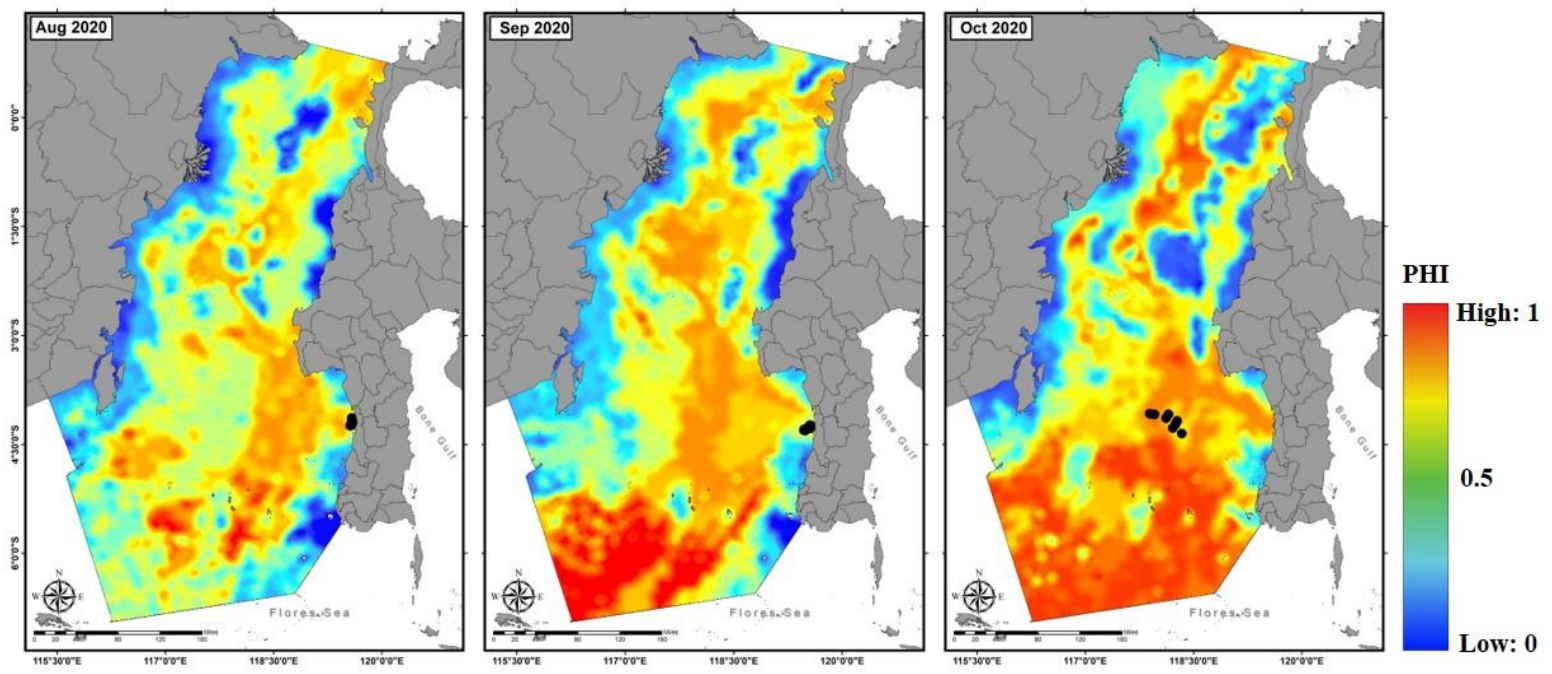

Figure 7. The spatial distribution of skipjack tuna fishing spots (black dots) from August to October 2020 superimposed on the hotspot based on the PHI area

\section{Discussion}

Spatially and temporally, environmental parameters have a significant effect on the events that occur in water. Several environmental parameters are used to predict fish habitats and show a positive response. Several studies have even proven that oceanographic parameters have high significance for the distribution of fish in the waters (Wang et al. 2016; Artetxe-Arrate et al. 2020; Syah et al. 2020). This study focused on skipjack tuna and its relationship with certain oceanographic factors (SST and SSC). Andrade and Garcia (1999) define the natural relationship between skipjack tuna and SST, suggesting that both biotic and abiotic factors are significant in this relationship (Andrade 2003). In sub-tropical waters, such as in Japan, the optimal SST for skipjack distribution is not less than $18^{\circ} \mathrm{C}$ (Kiyofuji et al. 2019). For tropical waters, temperature values are optimal between $28.5^{\circ} \mathrm{C}$ and close to $31.5^{\circ} \mathrm{C}$ (Zainuddin et al. 2013; Zainuddin et al. 2017). The ECDF method shows that the optimal SST range is $28.78-31.25^{\circ} \mathrm{C}$ (Figure 4.A). Apart from SST, SSC plays a vital role in the distribution of fish. Skipjack tuna can be clearly identified in waters with an optimum SSC concentration of $0.2 \mathrm{mg} \mathrm{m}^{-3}$ (Zainuddin et al. 2017). Nevertheless, SSC does not directly affect skipjack tuna's distribution (Hidayat et al. 2019b). The relation of SSC and skipjack tuna is more dependent on the indicators of skipjack tuna's feed, namely small pelagic fish such as anchovies (Stolephorus sp.) and others (Safruddin et al. 2018). Skipjack tuna and the other types of tropical tuna are certainly visual, opportunistic predators that eat various types of prey (Olson et al. 2016; Duffy et al. 2017). The dietary composition of tropical tuna will depend on body size, location, period, and depth (Olson et al. 2016). 

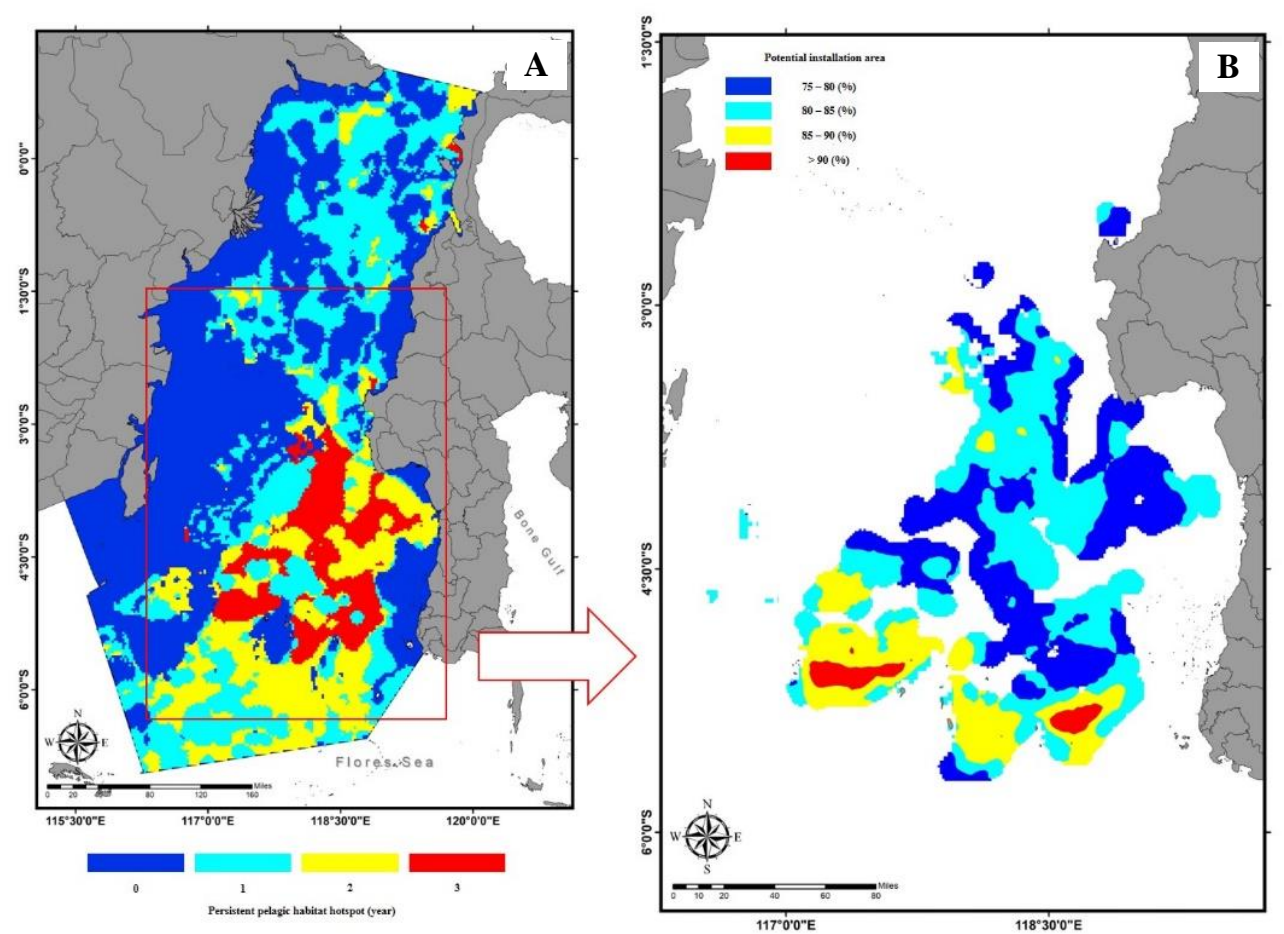

Figure 8.A. The persistent spatial distribution of pelagic habitat hotspots for skipjack tuna in the peak season of October 2017-2019; B. Spatial distribution of potential areas for setting FADs based on high pelagic hotspot values
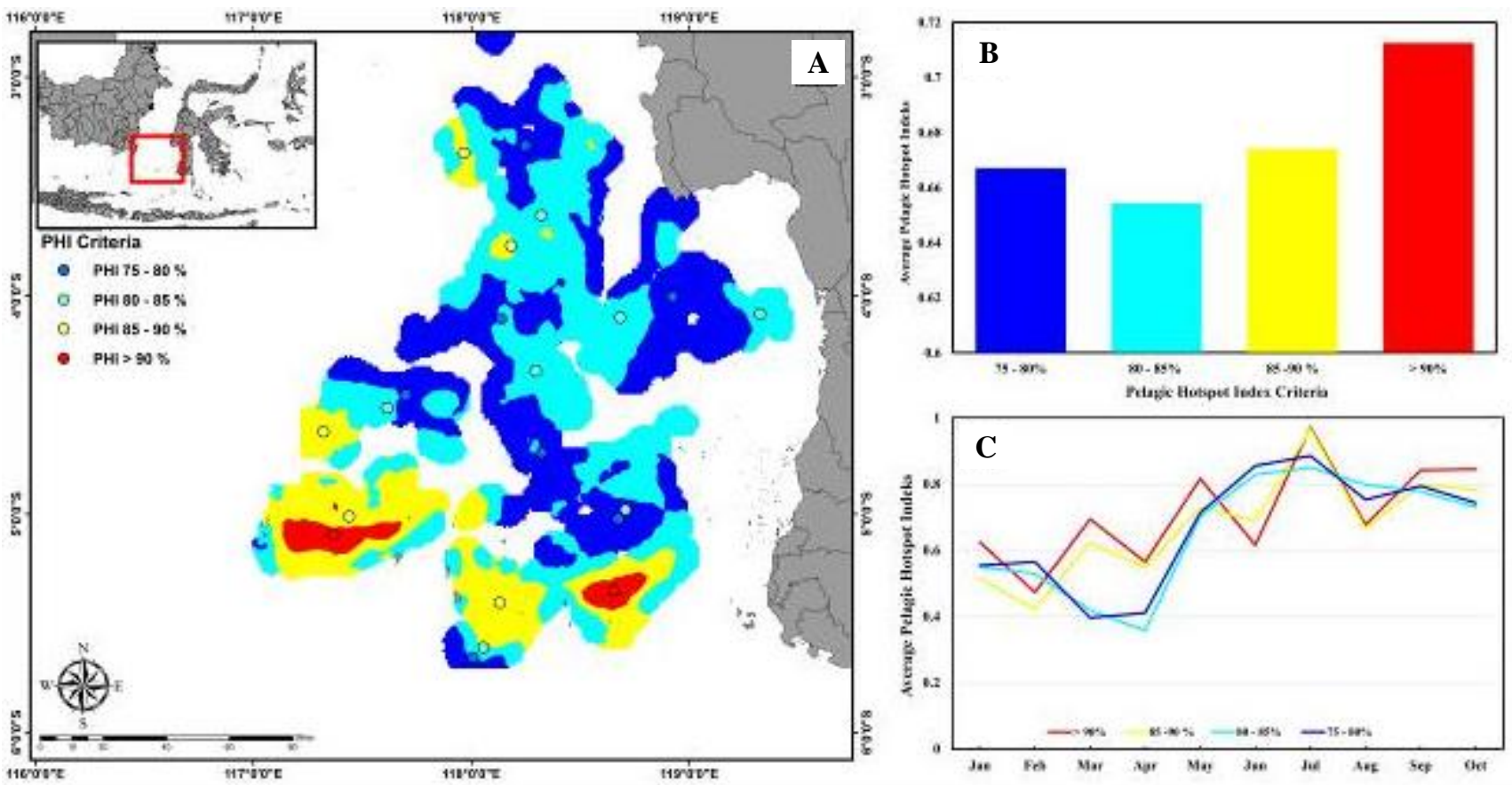

Figure 9.A. The prediction of potential areas for setting FADs based on the PHI criteria; B. A graphic of the pelagic hotspot index criteria in relation to the average pelagic hotspot index; C. The average performance of potential areas for setting FADs setting in January to October 2020

The Makassar Strait is unique. The Indonesian Throughflow makes the distribution of oceanographic parameters very dynamic (Gordon 2005). Even with very dynamic fluctuations of SST and SSC in the waters, it results in alternating upwelling and downwelling events
(Atmadipoera and Widyastuti 2015; Sari et al. 2018; Wijaya et al. 2020) and has the potential to cause biological responses in water (Iskandar et al. 2017; Takarina et al. 2019). The distribution of skipjack tuna in the waters correlates to the thermal front location, not far from the 
chlorophyll- $a$ front area (Hidayat et al. 2019a). These events are mainly related to SSC and SST (Zainuddin et al. 2019) and corroborate our argument for determining the habitat of skipjack tuna using these two parameters. This study resulted in a high $\mathrm{PHI}$ value $(\mathrm{PHI}>75 \%)$ to identify areas with fishing opportunities. PHI can show suitable fishing areas (Figures 6 and 7), supported by the potential for upwelling zones (Atmadipoera and Widyastuti 2015) and eddy events (Nuzula et al. 2017; Hidayat and Zainuddin 2019) in this area. The test results also showed a consistent pattern of high PHI values in the southern Makassar Strait from January to October 2020 (Figure 9).

Positive results from the determination of the habitat of skipjack tuna in the Makassar Strait can be a reference for setting FADs. FADs are very effective tools for increasing fish production in waters (Macusi et al. 2017a; Macusi et al. 2017b). The existence of skipjack tuna in FAD areas is caused by the natural behavior of fish to be attracted to floating objects (Matsumoto et al. 2016); this will be constructive for catching fish in a specific area. In addition, skipjack tuna is easy to get food in the FAD area because FAD has an attractor that can be a shelter from small pelagic fish (Mallawa et al. 2021). It is necessary to admit that so far, the installation of FADs in the waters without improved management and good governance will impact the assessment of FADs as unsustainable tools (Dagorn et al. 2013; Leroy et al. 2013). The characteristics of suitable habitats in the setting of FADs are expected to reduce the harmful effects of FADs, such as the number of by-catches caught.

This study discusses the determination of potential areas to be used as a reference for setting FADs for skipjack tuna, thus offering the potential for sustainability for this tool. The role of oceanographic parameters is significant in selecting FAD targets. As in SST, although tropical tuna species are often equated with circumtropical species that inhabit marine pelagic areas in the world's oceans, there is a difference where skipjack tuna inhabits the epipelagic zone (surface up to $50 \mathrm{~m}$ ), especially on mixed surfaces layer above the thermocline and waters with SST from 18 to $31^{\circ} \mathrm{C}$ (Pecoraro et al. 2017). In this study, the potential SST for skipjack tuna in the Makassar Strait was around $29^{\circ} \mathrm{C}$ (Figure 5.A and Figure 5.C). Other species such as yellowfin tuna and bigeye tuna inhabit mesopelagic waters (50 to $1000 \mathrm{~m}$ deep) (Goujon and Majkowski 2010). Typically, yellowfin tuna is at a temperature of 15 to $18.9^{\circ} \mathrm{C}$ (Song et al. 2008), and bigeye tuna is at 12 to $13.9^{\circ} \mathrm{C}$ (Song et al. 2009). The use of surface FADs is considered a solution to avoid catching other than skipjack tuna because, for the waters of FMA 713 , the status of utilization of other tuna species other than skipjack tuna has been over-exploited (KKP 2017). In addition, using fishing gear with a high selectivity value such as pole-and-line is also vital to reduce bycatch. The case is related to regulation and sustainable fisheries management. Combining Habitats that follow a suitable range of oceanographic parameter tolerances for skipjack tuna will significantly assist the accuracy of FADs.

To conclude, this study indicates that the SST and SSC accurately identify the skipjack tuna habitat in the
Makassar Strait (Figure 6 and Figure 7). Spatially and temporally, the Makassar Strait has potential areas for the setting of FADs. The correct habitat, combined with the skipjack tuna's tendency to be attracted to floating objects, can suggest the ideal location for setting FADs. The best areas for setting FADs are represented by criteria 4 and 3 with PHI characteristics $>90 \%$ and $85-90 \%$ respectively in the southern Makassar Strait. This research is expected to contribute and be a reference in the management and sustainable development of skipjack tuna fisheries.

\section{ACKNOWLEDGEMENTS}

We thank NASA's Ocean Color (https://oceancolor.gsfc.nasa.gov/) for the free open data. We also thank the Ministry of Research, Technology, and Higher Education of the Republic of Indonesia for funding this study under the PMDSU scholarship program (research Grant No. 1739/UN4.21/PL.01.10/2019).

\section{REFERENCES}

Andrade HA. 2003. The relationship between the skipjack tuna (Katsuwonus pelamis) fishery and seasonal temperature variability in the south-western Atlantic. Fish Oceanogr 12 (1): 10-18. DOI: 10.1046/j.1365-2419.2003.00220.x

Andrade HA, Garcia CAE. 1999. Skipjack tuna fishery in relation to sea surface temperature off the southern Brazilian coast. Fish Oceanogr 8 (4): 245-254. DOI: 10.1046/j.1365-2419.1999.00107.x

Artetxe-Arrate I, Fraile I, Marsac F, Farley JH, Rodriguez-Ezpeleta N, Davies CR, Clear NP, Grewe P, Murua H. 2020. A review of the fisheries, life history and stock structure of tropical tuna (skipjack Katsuwonus pelamis, yellowfin Thunnus albacares and bigeye Thunnus obesus) in the Indian Ocean. Adv Mar Biol 88: 39-89. DOI: 10.1016/bs.amb.2020.09.002

Atmadipoera AS, Widyastuti P. 2015. A numerical modeling study on upwelling mechanism in Southern Makassar Strait. Jurnal Ilmu dan Teknologi Kelautan Tropis 6 (2): 355-372. DOI: 10.29244/jitkt.v6i2.9012

Cheung WWL, Lam VWY, Sarmiento JL, Kearney K, Watson R, Pauly D. 2009. Projecting global marine biodiversity impacts under climate change scenarios. Fish Fish 10 (3): 235-251. DOI: 10.1111/j.14672979.2008.00315.x

Dagorn L, Filmalter JD, Forget F, Amandè MJ, Hall MA, Williams P, Murua H, Ariz J, Chavance P, Bez N. 2012. Targeting bigger schools can reduce ecosystem impacts of fisheries. Can J Fish Aquat Sci 69 (9): 1463-1467. DOI: 10.1139/F2012-089

Dagorn L, Holland KN, Restrepo V, Moreno G. 2013. Is it good or bad to fish with FADs? What are the real impacts of the use of drifting FADs on pelagic marine ecosystems? Fish Fish 14 (3): 391-415. DOI: 10.1111/j.1467-2979.2012.00478.x

Davies TK, Mees CC, Milner-Gulland EJ. 2014. The past, present and future use of drifting fish aggregating devices (FADs) in the Indian Ocean. Mar Policy 45: 163-170. DOI: 10.1016/j.marpol.2013.12.014

Duffy LM, Kuhnert PM, Pethybridge HR, Young JW, Olson RJ, Logan JM, Goñi N, Romanov E, Allain V, Staudinger MD, Abecassis M, Choy CA, Hobday AJ, Simier M, Galván-Magaña F, Potier M, Ménard F. 2017. Global trophic ecology of yellowfin, bigeye, and albacore tunas: Understanding predation on micronekton communities at ocean-basin scales. Deep Res Part II Top Stud Oceanogr 140: 5573. DOI: $10.1016 /$ j.dsr2.2017.03.003

FAO. 2016. The State of World Fisheries and Aquaculture 2016. Contributing to Food Security and Nutrition for All Food and Agriculture Organization, Rome.

FAO. 2018. The State of World Fisheries and Aquaculture 2018. Meeting the Sustainable Development Goals. Food and Agriculture Organization, Rome. 
França S, Vasconcelos RP, Fonseca VF, Tanner SE, Reis-Santos P, Costa MJ, Cabral HN. 2012. Predicting fish community properties within estuaries: Influence of habitat type and other environmental features. Estuar Coast Shelf Sci 107: 22-31. DOI: 10.1016/j.ecss.2012.04.013

Galland G, Rogers A, Nickson A. 2016. Netting Billions: A Globa Valuation of Tuna. [Report]. Pew Charitable Trust, United States.

Gordon AL. 2005. Oceanography of the Indonesia Seas and their throughflow. Oceanogr 18 (4): 14-27. DOI: 10.5670/oceanog.2005.01

Goujon M, Majkowski C. 2010. Biological characteristics of tuna. FAO Fish Aquac Dep. http://www.fao.org/fishery/topic/16082/en

Guisan A, Edwards TC, Hastie T. 2002. Generalized linear and generalized additive models in studies of species distributions: Setting the scene. Ecol Modell 157: 89-100. DOI: 10.1111/j.13653040.1985.tb01209.x

Hallier JP, Gaertner D. 2008. Drifting fish aggregation devices could act as an ecological trap for tropical tuna species. Mar Ecol Prog Ser 353 255-264. DOI: $10.3354 /$ meps07180

Hidayat R, Zainuddin M. 2019. Detection of cyclonic and anti-cyclonic eddy in relation to potential Skipjack Tuna fishing ground in Makassar Strait. IOP Conf Ser Earth Environ Sci 241 (1): 012011 DOI: $10.1088 / 1755-1315 / 241 / 1 / 012011$

Hidayat R, Zainuddin M, Mallawa A, Mustapha MA, Safruddin, Putri ARS. 2020. Estimating potential fishing zones for Skipjack Tuna (Katsuwonus pelamis) Abundance in Southern Makassar Strait. IOP Conf Ser Earth Environ Sci 564 (1): 012082. DOI: 10.1088/17551315/564/1/012082

Hidayat R, Zainuddin M., Safruddin S, Mallawa A, Farhum SA, 2019a. Skipjack Tuna (Katsuwonus pelamis) catch in relation to the Therma and Chlorophyll-a Fronts during May - July in the Makassar Strait IOP Conf Ser Earth Environ Sci 253 (1): 012045. DOI 10.1088/1755-1315/253/1/012045

Hidayat R, Zainuddin M, Putri ARS. 2019b. Skipjack tuna (Katsuwonus pelamis) catches in relation to chlorophyll-a front in Bone Gulf during the southeast monsoon. AACL Bioflux 12 (1): 209-218.

Iskandar I, Sari QW, Setiabudiday D, Yustian I, Monger B. 2017. The distribution and variability of chlorophyll-a bloom in the southeastern tropical Indian ocean using empirical orthogonal function analysis. Biodiversitas 18 (4): 1546-1555. DOI: 10.13057/biodiv/d180433

ISSF. 2020. Status of the World Fisheries for Tuna. [Report]. ISSF, Washington DC, USA.

Johnson JB, Omland KS. 2004. Model selection in ecology and evolution. Trends Ecol Evol 19 (2): 101-108. DOI: 10.1016/j.tree.2003.10.013

Khan AMA, Nasution AM, Purba NP, Rizal A, Hamdani H, Dewanti LP, Nurruhwati I, Sahidin A, Supriyadi D, Herawati H, Apriliani IM, Ridwan M, Gray TS, Jiang M, Arief H, Mill AC, Polunin NVC. 2020. Oceanographic characteristics at fish aggregating device sites for tuna pole and line fishery in eastern Indonesia. Fish Res 225: 105471. DOI: 10.1016/j.fishres.2019.105471

Kiyofuji H, Aoki Y, Kinoshita J, Okamoto S, Masujima M, Matsumoto T, Fujioka K, Ogata R, Nakao T, Sugimoto N, Kitagawa T. 2019. Northward migration dynamics of skipjack tuna (Katsuwonus pelamis) associated with the lower thermal limit in the western Pacific Ocean. Prog Oceanogr 175: 55-67. DOI: 10.1016/j.pocean.2019.03.006

KKP. 2017. Decree of the Ministry of Marine Affairs and Fisheries of the Republic of Indonesia Number 50/KEPMEN-KP/2017 on Stock Estimation, Allowable Catch, and Exploitation Levels of Fisheries Resources in the Indonesian Fisheries Management Areas. [Indonesian]

Kunarso, Hadi S, Ningsih NS, Baskoro MS. 2011. Variabilitas suhu dan klorofil-a di daerah upwelling pada variasi kejadian ENSO dan IOD di Perairan Selatan Jawa sampai Timor. Ilmu Kelautan 16 (3): 171 180. DOI: 10.14710/ik.ijms.163.171-180. [Indonesian]

Leroy B, Phillips JS, Nicol S, Pilling GM, Harley S, Bromhead D, Hoyle S, Caillot S, Allain V, Hampton J. 2013. A critique of the ecosystem impacts of drifting and anchored FADs use by purse-seine tuna fisheries in the Western and Central Pacific Ocean. Aquat Living Resour 26 (1): 49-61. DOI: 10.1051/alr/2012033

Lezama-Ochoa N, Murua H, Ruiz J, Chavance P, Molina, ADd, Caballero A, Sancristobal I. 2018. Biodiversity and environmenta characteristics of the bycatch assemblages from the tropical tuna purse seine fisheries in the eastern Atlantic Ocean. Mar Ecol 39 (3): 1-18. DOI: $10.1111 / \mathrm{maec} .12504$

Macusi ED, Abreo NAS, Babaran RP. 2017a. Local ecological knowledge (LEK) on fish behavior around anchored FADs: The case of tuna purse seine and ringnet fishers from Southern Philippines. Front Mar Sci 4: 1-13. DOI: 10.3389/fmars.2017.00188

Macusi ED, Katikiro RE, Babaran RP. 2017b. The influence of economic factors in the change of fishing strategies of anchored FAD fishers in the face of declining catch, General Santos City, Philippines. Mar Policy 78: 98-106. DOI: 10.1016/j.marpol.2017.01.016

Malakoff D. 2004. New tools reveal treasures at ocean hot spots. Mar Sci 304: 1104-1105. DOI: 10.1126/science.304.5674.1104

Mallawa A, Amir F, Safruddin, Mallawa E, 2018. Keberlanjutan teknologi penangkapan ikan cakalang (Katsuwonus pelamis) di perairan Teluk Bone, Sulawesi Selatan. Mar Fish 9 (1): 93-106. DOI: 10.29244/jmf.9.1.97-110. [Indonesian]

Mallawa A, Amir F, Halid I. 2021. Comparison of the catch of two fishing technologies for yellowfin tuna (Thunnus albacares Bonnaterre 1788) in Bone Bay waters, South Sulawesi Indonesia. IOP Conf Ser Earth Environ Sci 718 (1): 012077. DOI: 10.1088/1755-1315/718/1/012077

Marsac F, Fonteneau A, Ménard F. 2000. Drifting FADs used in tuna fisheries: An ecological trap? Proc 1st Symp Tuna Fish FADs, Martinique, Oct. 1999 537-552.

Marshall CT, Morgan MJ, Murua H, Kraus G, Lambert Y, Marteinsdo G, Brien LO, Tomkiewicz J. 2009. The evaluation of reference points and stock productivity in the context of alternative indices of stock reproductive potential. Can J Fish Aquat Sci 66: 404-414. DOI: 10.1139/F09-009

Matsumoto T, Satoh K, Semba Y, Toyonaga M. 2016. Comparison of the behavior of skipjack (Katsuwonus pelamis), yellowfin (Thunnus albacares) and bigeye (T. obesus) tuna associated with drifting FADs in the equatorial central Pacific Ocean. Fish Oceanogr 25 (6): 565581. DOI: 10.1111/fog. 12173

Mugo R, Saitoh SI, Nihira A, Kuroyama T. 2010. Habitat characteristics of skipjack tuna (Katsuwonus pelamis) in the western North Pacific: A remote sensing perspective. Fish Oceanogr 19 (5): 382-396. DOI: 10.1111/j.1365-2419.2010.00552.x

Nuzula F, Syamsudin ML, Yuliadi LPS, Purba NP, Martono. 2017. Eddies spatial variability at Makassar Strait - Flores Sea. IOP Conf Ser Earth Environ Sci 54 (1): 012079. DOI: 10.1088/1755-1315/54/1/012079

Olson RJ, Young JW, Ménard F, Potier M, Allain V, Goñi N, Logan JM, Galván-Magaña F. 2016. Bioenergetics, trophic ecology, and niche separation of tunas. Adv Mar Biol 74: 199-344. DOI: 10.1016/bs.amb.2016.06.002

Palacios DM, Bograd SJ, Foley DG, Schwing FB. 2006. Oceanographic characteristics of biological hot spots in the North Pacific: A remote sensing perspective. Deep Res Part II Top Stud Oceanogr 53 (3-4): 250-269. DOI: 10.1016/j.dsr2.2006.03.004

Pecoraro C, Zudaire I, Bodin N, Murua H, Taconet P, Díaz-Jaimes P, Cariani A, Tinti F, Chassot E. 2017. Putting all the pieces together: integrating current knowledge of the biology, ecology, fisheries status, stock structure and management of yellowfin tuna (Thunnus albacares). Rev Fish Biol Fish 27: 811-841. DOI: 10.1007/s11160016-9460-Z

Polovina JJ, Howell EA. 2005. Ecosystem indicators derived from satellite remotely sensed oceanographic data for the North Pacific. ICES J Mar Sci 62 (3): 319-327. DOI: 10.1016/j.icesjms.2004.07.031

Rodriguez-Tress P, Capello M, Forget F, Soria M, Beeharry SP, Dussooa N, Dagorn L. 2017. Associative behavior of yellowfin Thunnus albacares, skipjack Katsuwonus pelamis, and bigeye tuna T. obesus at anchored fish aggregating devices (FADs) off the coast of Mauritius. Mar Ecol Prog Ser 570: 213-222. DOI: 10.3354/meps12101

Romanov EV. 2008. Bycatch in the soviet purse seine tuna fisheries on fad-associated schools in north equatorial area of the western Indian ocean. West Indian Ocean J Mar Sci 7 (2): 163-174.

Safruddin, Hidayat R, Zainuddin M. 2018. Effects of environmental factors on anchovies Stolephorus sp distribution in bone Gulf, Indonesia. AACL Bioflux 11 (2): 387-393.

Safruddin, Aswar B, Ashar MR, Hidayat R, Dewi YK, Umar MT, Farhum SA, Mallawa A, Zainuddin M. 2019. The fishing ground of large pelagic fish during the southeast monsoon in Indonesian Fisheries Management Area-713. IOP Conf Ser Earth Environ Sci 370 (1): 012045. DOI: $10.1088 / 1755-1315 / 370 / 1 / 012045$

Sari QW, Siswanto E, Setiabudidaya D, Yustian I, Iskandar I. 2018. Spatial and temporal variability of surface chlorophyll-a in the gulf of Tomini, Sulawesi, Indonesia. Biodiversitas 19 (3): 743-751. DOI: 10.13057/biodiv/d190306

Song L, Zhou J, Zhou Y, Nishida T, Jiang W, Wang J. 2009. Environmental preferences of bigeye tuna, Thunnus obesus, in the 
Indian Ocean: An application to a longline fishery. Environ Biol Fishes 85 (2): 153-171. DOI: 10.1007/s10641-009-9474-7

Song LM, Zhang Y, Xu LX, Jiang WX, Wang JQ. 2008. Environmental preferences of longlining for yellowfin tuna (Thunnus albacares) in the tropical high seas of the Indian Ocean. Fish Oceanogr 17 (4): 239 253. DOI: $10.1111 / j .1365-2419.2008 .00476 . x$

Syah AF, Gaol JL, Zainuddin M, Apriliya NR, Berlianty D, Mahabrort D. 2020. Detection of potential fishing zones of Bigeye tuna (Thunnus obesus) at profundity of $155 \mathrm{M}$ in the eastern Indian Ocean. Indones $\mathrm{J}$ Geogr 52 (1): 29-35. DOI: 10.22146/ijg.43708

Sydeman WJ, Brodeur RD, Grimes CB, Bychkov AS, McKinnell S. 2006. Marine habitat "hotspots", and their use by migratory species and top predators in the North Pacific Ocean: Introduction. Deep Res II 53: 247-249. DOI: 10.1016/j.dsr2.2006.03.001

Takarina ND, Nurliansyah W, Wardhana W. 2019. Relationship between environmental parameters and the plankton community of the Batuhideung fishing grounds, Pandeglang, Banten, Indonesia. Biodiversitas 20 (1): 171-180. DOI: 10.13057/biodiv/d200120

Taquet M. 2013. Fish aggregating devices (FADs): Good or bad fishing tools? A question of scale and knowledge. Aquat Living Resour 26 (1): 25-35. DOI: 10.1051/alr/2013043

Tseng CT, Sun CL, Yeh SZ, Chen SC, Su WC. 2010. Spatio-temporal distributions of tuna species and potential habitats in the Western and Central Pacific Ocean derived from multi-satellite data. Intl J Remote Sens 31: 4543-4558. DOI: 10.1080/01431161.2010.485220

Wang J, Chen X, Chen Y. 2016. Spatio-temporal distribution of skipjack in relation to oceanographic conditions in the west-central Pacific Ocean. Intl J Remote Sens 37 (24): 6149-6164. DOI: 10.1080/01431161.2016.1256509
Wijaya A, Zakiyah U, Sambah AB, Setyohadi D. 2020. Spatio-temporal variability of temperature and chlorophyll-a concentration of sea surface in Bali Strait, Indonesia. Biodiversitas 21 (11): 5283-5290. DOI: $10.13057 /$ biodiv/d211132

Worm B, Lotze HK, Myers RA. 2003. Predator diversity hotspots in the blue ocean. Proc Natl Acad Sci USA 100 (17): 9884-9888. DOI: 10.1073/pnas.1333941100

Yuniarti A, Maslukah L, Helmi M. 2013. Studi variabilitas suhu permukaan laut berdasarkan citra satelit aqua MODIS Tahun 20072011 di Perairan Selat Bali. J Oceanogr 2 (4): 416-421. [Indonesian]

Zainuddin M, Saitoh K, Saitoh SI. 2008. Albacore (Thunnus alalunga) fishing ground in relation to oceanographic conditions in the western North Pacific Ocean using remotely sensed satellite data. Fish Oceanogr 17 (2): 61-73. DOI: 10.1111/j.1365-2419.2008.00461.x

Zainuddin M, Nelwan A, Farhum SA, Najamuddin, Hajar MAI, Kurnia M, Sudirman. 2013. Characterizing potential fishing zone of skipjack tuna during the southeast monsoon in the Bone Bay-Flores Sea using remotely sensed oceanographic data. Intl J Geosci 4 (1): 259-266. DOI: 10.4236/ijg.2013.41a023

Zainuddin M, Farhum SA, Safruddin S, Selamat MB, Sudirman S, Nurdin N, Syamsuddin M, Ridwan M, Saitoh SI. 2017. Detection of pelagic habitat hotspots for skipjack tuna in the Gulf of Bone-Flores Sea, southwestern Coral Triangle tuna, Indonesia. PLoS One 12 (10): 1-19. DOI: 10.1371/journal.pone.0185601

Zainuddin M, Amir MI, Bone A, Farhum SA, Hidayat R, Putri ARS, Mallawa A, Safruddin, Ridwan M. 2019. Mapping distribution patterns of skipjack tuna during January-May in the Makassar Strait. IOP Conf Ser Earth Environ Sci 370 (1): 012004. DOI: $10.1088 / 1755-1315 / 370 / 1 / 012004$ 